\title{
Efektivitas Laboratorium Virtual Kimia Berbasis Hypertext Markup Language 5 Untuk Meningkatkan Sikap Ilmiah Dan Prestasi Belajar
}

\author{
Firdiawan Ekaputra ${ }^{1}$ \\ ${ }^{1}$ Universitas Negeri Yogyakarta
}

\section{Info Artikel :}

Diterima 16 April 2020

Direvisi 20 April 2020

Dipublikasikan 27 April 2020

Kata Kunci:
Laboratorium virtual kimia
berbasis hypertext markup
language 5
Sikap ilmiah
Prestasi belajar

Keywords:

Hypertext markup language 5 based virtual chemistry laboratory

Scientific attitude

Learning achievement

\begin{abstract}
ABSTRAK
Penelitian ini bertujuan untuk menguji peningkatan sikap ilmiah dan prestasi belajar peserta didik kelas XI SMA 1 Godean dengan penerapan LVK berbasis HTML5 dibanding peserta didik tanpa penerapan LVK berbasis HTML5 pada materi Laju Reaksi. Penelitian ini merupakan penelitian eksperimen dengan satu faktor, dua variabel. Uji coba lapangan pemanfaatan LVK berbasis HTML5 adalah melalui hybrid learning. Sampel uji coba lapangan terdiri dari kelas dengan penerapan LVK berbasis HTML5 sebagai kelas eksperimen dan kelas yang tanpa penerapan LVK berbasis $H T M L 5$ sebagai kelas kontrol. Data yang terkumpul dianalisis menggunakan manova untuk menguji pengaruh penerapan LVK berbasis HTML5 terhadap sikap ilmiah dan prestasi belajar. Hasil penelitian menunjukkan terdapat peningkatan sikap ilmiah dan prestasi belajar yang lebih baik pada peserta didik kelas XI SMA 1 Godean dengan penerapan LVK berbasis HTML5 dibanding peserta didik tanpa penerapan LVK berbasis HTML5 pada materi Laju Reaksi.
\end{abstract}

\begin{abstract}
This study aims to examine the improvement of students' scientific attitude and learning achievement of grade XI SMA 1 Godean who used HTML5-based VCL compared to the student who did not use HTML5-based VCL on the reaction rate material. This research was designed as an experimental research with one factor, two variables. The field-testing of HTML5-based VCL utilization was through a hybrid learning. Field-testing sample consisted of the experimental class implementing HTML5-based VCL and the control class without utilizing HTML5-based VCL. The collected data were analyzed using MANOVA to test the influence of the product implementation toward the students'scientific attitude and learning achievement. The results show there are differences in improvement of the students' scientific attitude and learning achievement in the experimental class and control class toward the reaction rate material.
\end{abstract}

\section{Koresponden:}

Firdiawan Ekaputra,

Email: firdiawan.ekaputra@gmail.com work is properly cited. 02019 by author.

\section{Pendahuluan}

Ilmu pengetahuan dan teknologi berkembang begitu pesat. Informasi dari belahan bumi yang satu dapat menyebar ke belahan bumi lainnya dalam hitungan detik karena adanya perkembangan ilmu pengetahuan dan teknologi. Kebutuhan akan penyampaian informasi yang cepat dibutuhkan oleh seluruh lapisan masyarakat termasuk di dalam dunia pendidikan. Penerapan Kurikulum 2013 sebagai standar penyelenggaraan pendidikan merupakan langkah untuk memperbaiki kualitas pendidikan dan mengikuti perkembangan ilmu pengetahuan dan teknologi.

Kurikulum 2013 merupakan kurikulum yang berbasis pada scientific approach yang meliputi mengamati, menanya, mengumpulkan informasi, mengasosiasi, dan mengkomunikasikan untuk semua mata pelajaran. Proses pembelajaran pada Kurikulum 2013 bersifat interaktif, berbasis kontekstual, dan berpusat pada peserta didik. Pembelajaran pada Kurikulum 2013 memperkuat proses pembelajaran dan penilaian otentik untuk mencapai kompetensi sikap, pengetahuan, dan keterampilan. Penilaian otentik meliputi kesiapan peserta didik dalam mengikuti pembelajaran, proses, dan hasil belajar secara keseluruhan (Mendikbud, 2013). 
Berdasarkan pengamatan awal yang dilakukan, prestasi belajar peserta didik kelas XI SMA Negeri 1 Godean DIY pada materi Laju Reaksi masih rendah yang ditunjukkan dengan tingkat capaian hasil belajar peserta didik sebesar 67,92\%. Rendahnya tingkat capaian materi Laju Reaksi disebabkan media pembelajaran yang diterapkan kurang menarik perhatian peserta didik dan terkesan monoton, sehingga peserta didik menjadi jenuh dan pasif dalam mengikuti proses pembelajaran, dan rasa keingintahuan peserta didik terhadap materi yang disampaikan guru rendah.

Sadiman, et al. (1984: 11) menyatakan bahwa media pembelajaran sebagai salah satu sumber belajar dapat menyalurkan pesan sehingga dapat mengatasi faktor yang mempengaruhi motivasi dan prestasi belajar. Kemp \& Dayton (Susilana \& Riyana, 2008: 9) menyatakan bahwa penerapan media pembelajaran dapat menciptakan pembelajaran menjadi lebih interaktif, waktu pelaksanaan pembelajaran dapat dipersingkat, dan dapat meningkatkan kualitas pembelajaran. Pemanfaatan media pembelajaran laboratorium virtual dapat menjadikan proses pembelajaran menjadi lebih menarik dan interaktif, jumlah tatap muka dalam kelas dapat berkurang karena dapat dijadikan sumber belajar mandiri. Pendidik tetap dapat memantau aktivitas belajar pserta didik karena media laboratorium virtual terhubung dengan internet. Kondisi ini juga dikemukakan Aprianto (2008: 22) yang menyatakan bahwa pemanfaatan media laboratorium virtual secara online dapat memperbaiki sistem pengajaran, sehingga peserta didik menjadi lebih aktif dan materi kuliah yang lebih dinamis karena dapat dilakukan dimana saja dan kapan saja. Kekurangan pemanfaatan media laboratorium virtual secara online merupakan bandwidth yang kecil dapat mengakibatkan lamanya waktu akses, oleh karena itu dalam pengembangan laboratorium virtual kimia (LVK) secara online yang dikembangan menggunakan Hypertext Markup Language 5 (HTML5) yang diharapkan dapat meningkatkan kecepatan akses media. Berdasarkan hal tersebut, pada penelitian ini diterapkan media pembelajaran LVK berbasis HTML5 dengan materi Laju Reaksi untuk meningkatkan sikap ilmiah dan prestasi belajar peserta didik kelas XI di SMA Negeri 1 Godean.

\section{Metode}

Penelitian ini merupakan jenis penelitian kuasi eksperimen dengan rancangan nonequivalent control-group design. Subjek uji efektivitas menggunakan media pembelajaran terdiri dari dua kelas di SMA Negeri 1 Godean, yaitu kelas eksperimen yang terdiri dari 31 peserta didik dan kelas kontrol yang terdiri 32 peserta didik. Teknik pengumpulan data penelitian ini menggunakan tiga macam teknik pengumpulan data, yaitu teknik dokumentasi, observasi dan angket, serta soal. Teknik dokumentasi digunakan untuk mengumpulkan informasi selama pelaksanaan kegiatan pembelajaran kelas XI SMA Negeri 1 Godean pada materi Laju Reaksi. Teknik observasi dan angket digunakan untuk mengumpulkan data sikap ilmiah pesserta didik pada materi pokok Laju Reaksi sebelum dan saat penerapan media pembelajaran LVK berbasis HTML5 dan peserta didik tanpa penerapan media pembelajaran LVK berbasis HTML5. Teknik soal dalam penelitian ini terdiri dari soal prestasi belajar. Soal prestasi belajar yang akan diterapkan pada kelas eksperimen dan kontrol telah dilakukan uji validasi secara logis dan empiris. Validasi logis dipenuhi dengan menyusun kisikisi soal, sedangkan validasi empiris dipenuhi dengan mengujikan soal kepada peserta didik selain kelas eksperimen maupun kelas kontrol.

Instrumen yang digunakan dalam penelitian ini adalah RPP, lembar observasi sikap ilmiah, angket sikap ilmiah, soal prestasi belajar, serta media pembelajaran LVK berbasis HTML5. RPP merupakan instrumen untuk memberi perlakuan pada kedua kelas sampel dengan materi Laju Reaksi. Pada penelitian ini, RPP yang digunakan yaitu RPP dengan penerapan media pembelajaran LVK berbasis HTML5 dan RPP tanpa penerapan media pembelajaran LVK berbasis HTML5. Lembar observasi digunakan untuk menguji sikap ilmiah peserta didik kelas eksperimen maupun kelas kontrol. Angket sikap ilmiah digunakan untuk menguji sikap ilmiah peserta didik kelas eksperimen maupun kontrol. Angket diisi oleh peserta didik sebelum dan selama proses pembelajaran untuk materi Laju Reaksi. Soal prestasi belajar berupa soal uraian. Soal prestasi belajar sebelumnya dilakukan validasi secara logis dan empiris. Dalam memenuhi validasi soal secara logis, peneliti meyusun kisi-kisi soal prestasi belajar dengan memperhatikan sebaran tingkat pengetahuannya, mulai dari C1 sampai C6 yang meliputi kemampuan mengingat, memahami, menerapkan, menganalisis, mengevaluasi, dan mencipta.

Validasi empiris diperoleh dengan cara mengujikan soal prestasi belajar pada kelas selain kelas yang diberi penerapan LVK berbasis HTML5. Soal prestasi belajar yang telah dilakukan validasi akan diterapkan pada awal pembelajaran sebagai pretest dan akhir pembelajaran dengan materi Laju Reaksi sebagai posttest. LVK berbasis HTML5 terdiri dari materi Laju Reaksi dan lembar kerja peserta didik pada setiap akhir yang 
dapat dikerjakan peserta didik di sekolah maupun di rumah secara online, serta LVK untuk memberikan penjelasan mengenai prosedur percobaan dan reaksi yang terjadi berdasarkan percobaan yang dilakukan.

Uji hipotesis dalam penelitian ini menggunakan uji manova untuk menguji perbedaan peningkatan sikap ilmiah dan prestasi belajar peserta didik kelas XI SMA Negeri 1 Godean yang diberi pembelajaran menggunakan LVK berbasis HTML5 dibanding peserta didik tanpa tanpa LVK berbasis HTML5. Adanya perbedaan perbedaan peningkatan sikap ilmiah dan prestasi belajar peserta didik dengan penerapan media LVK berbasis HTML5 dibanding peserta didik yang diberi tanpa penerapan media LVK berbasis HTML5 pada materi Laju Reaksi bila diperoleh signifikan kurang dari 0,05 atau $\mathrm{H}_{0}$ ditolak. Hipotesis nol diujikan dengan menggunakan uji manova dengan rumus (Stevens, 2009: 148).

$$
\begin{aligned}
& \mathrm{F}=\frac{\mathrm{n}_{1}+\mathrm{n}_{2}-\mathrm{p}-1}{\left(\mathrm{n}_{1}+\mathrm{n}_{2}-2\right) \mathrm{p}} \mathrm{T}^{2} \\
& \mathrm{~T}^{2}=\frac{\mathrm{n}_{1} \mathrm{n}_{2}}{\mathrm{n}_{1}+\mathrm{n}_{2}}\left(\overline{\mathrm{Y}_{1}}-\overline{\mathrm{Y}_{2}}\right)^{\prime} \mathrm{S}^{-1}\left(\overline{\mathrm{Y}_{1}}-\overline{\mathrm{Y}_{2}}\right)
\end{aligned}
$$

Keterangan:

$\mathrm{n} 1$ = banyaknya data perlakuan pertama

n2 = banyaknya data perlakuan kedua

$\mathrm{p}=$ banyaknya variabel terikat

\section{Hasil dan Pembahasan}

Penelitian ini bertujuan untuk menguji peningkatan sikap ilmiah dan prestasi belajar peserta didik kelas XI SMA 1 Godean dengan penerapan LVK berbasis HTML5 dibanding peserta didik yang tanpa penerapan LVK berbasis HTML5 pada materi Laju Reaksi. Alur pertama dalam penelitian ini adalah memilih kelas eksperimen dan kontrol berdasarkan tujuan tertentu, yaitu berdasarkan karakteristik peserta didik yang hampir sama, jumlah peserta didik dalam satu kelas lebih dari 30, dan rata-rata hasil ulangan pada materi sebelumnya tidak berbeda secara signifikan, yaitu dengan menguji data dengan uji-t beda subjek dan diperoleh nilai signifikan 0,5 atau lebih besar dari 0,05 . Setelah diperoleh kedua kelas yang memenuhi kriteria tersebut, dilakukan penentuan kelas eksperimen dan kontrol dengan cara acak yaitu dengan mengundi.

Sikap ilmiah awal peserta didik diperoleh dari hasil observasi pada pertemuan terakhir materi Termokimia atau sebelum melakukan pembelajran pada materi Laju Reaksi, sedangkan prestasi awal peserta didik diperoleh dari hasil pretest yang dilakukan baik kelas eksperimen maupun kontrol. Aspek sikap ilmiah yang dikembangkan dalam penelitian ini meliputi rasa ingin tahu, berfikir terbuka, berfikir kritis, dan bekerja sama. Sebelum angket dan lembar observasi sikap ilmiah peserta didik yang diujikan pada kelas eksperimen dan kontrol dilakukan uji validasi dan reliabilitas pada kelas di luar kelas sampel, sedangkan soal pretest dilakukan uji validasi, reliabilitas, uji beda, dan uji tingkat kesukaran dan pada kelas di luar kelas sampel.

Hasil sikap ilmiah awal dan pretest dari kelas eksperimen dan kontrol dlakukan uji normalitas dan homogenitas. Uji normalitas bertujuan untuk mengetahui apakah data dari setiap variabel berdistribusi normal atau tidak. Uji normalitas dilakukan terhadap data sikap ilmiah sebelum proses pembelajaran dan hasil pretest peserta didik pada kelas eksperimen maupun kontrol. Setelah dilakukan uji normalitas diperoleh harga signifikansi 0,200 untuk sikap ilmiah awal dan 0,200 untuk nilai pretest pada kelas eksperimen, sedangkan pada kelas kontrol diperoleh harga signifikansi 0,078 untuk sikap ilmiah awal dan 0,129 untuk nilai pretest. Harga signifikansi sikap ilmiah awal dan pretest pada kedua kelas lebih besar dari 0,05, sehingga dapat dinyatakan data dari kedua kelas tersebut terdistribusi normal.

Data sikap ilmiah awal dan pretest pada kelas eksperimen dan kontrol yang telah dilakukan uji normalitasnya, kemudian dilakukan uji homogenitas. Uji homogenitas berfungsi untuk mengetahui apakah sampel berasal dari populasi homogen atau tidak. Hasil uji homogenitas menunjukkan harga signifikansi 0,415 untuk data sikap ilmiah awal dan 0,919 untuk pretest. Kedua harga signifikansi tersebut lebih besar dari 0,05, sehingga kedua kelas berasal dari populasi yang homogen.

Observer melakukan pengamatan sikap ilmiah peserta didik selama proses pembelajaran materi Laju Reaksi dilaksanakan pada kelas eksperimen dan kontrol. Proses pembelajaran yang diterapkan pada kedua 
kelas baik RPP, lembar kerja peserta didik, dan tugas untuk dikerjakan di rumah oleh peserta didik sama, hanya saja yang membedakan adalah media yang diterapkan yaitu LVK berbasis HTML5 pada kelas eksperimen, sedangkan pada kelas kontrol menggunakan media powerpoint dan melakukan praktikum di laboratorium.

Peserta didik pada kelas eksperimen dan kontrol, diberikan tujuan dan manfaat diberikannya materi Laju Reaksi. Setelah diberikan pengantar mengenai materi, peserta didik berdiskusi untuk mengerjakan lembar kerja dan mencari jawaban dari referensi yang tersedia. Peserta didik terlihat aktif mencari jawaban, berdiskusi bersama teman sekelompok dan bertanya mengenai hal yang belum dipahami. Observer mencatat semua aktivitas peserta didik selama pembelajaran berlangsung. Peserta didik mempresentasikan hasil pekerjaan lembar kerja peserta didiknya di depan kelas, dilanjutkan dengan tanya jawab. Keaktifan peserta didik dalam tanya jawab menunjukkan bahwa peserta didik berpartisipasi aktif dalam proses pembelajar. Peneliti menjelaskan kembali materi terutama yang belum dipahami oleh peserta didik untuk mengurangi kesalahan konsep materi yang disampaikan. Pada akhir pertemuan peserta didik dibimbing membuat kesimpulan materi yang telah dipelajari dan memberikan tugas kepada peserta didik untuk dibahas pada pertemuan berikutnya.

Penelitian ini dilakukan selama empat minggu, dua minggu digunakan untuk menyampaikan materi Laju Reaksi, observasi sikap ilmiah awal dan pretest pada awal pertemuan minggu pertama dan satu minggu akhir digunakan untuk posttest peserta didik baik kelas eksperimen maupun kontrol. Selama proses pembelajaran, peserta didik kelas eksperimen lebih antusias mengikuti pelajaran terutama saat menggunakan LVK berbasis HTML5 sebagai media pengganti praktikum di laboratorium, karena hal tersebut merupakan hal yang baru untuk peserta didik.

Setelah diperoleh data hasil posttest dan sikap ilmiah pada pertemuan keempat dilakukan uji korelasi yang merupakan uji prasyarat hipotesis. Uji korelasi untuk menguji hubungan antara sikap ilmiah dengan prestasi belajar peserta didik. Hasil uji korelasi yang dilakukan diperoleh harga sigifikansi sebesar 0,046 yang menunjukkan adanya hubungan antara sikap ilmiah dan prestasi belajar yang diamati dalam penelitian ini. Kondisi ini sesuai dengan Bayram \& Comek (2009); Ayodele (2016); Singh, Singh, \& Giri (2016); Narmadha \& Chamundeswari (2013); Vijayakumara \& Lakshmi (2016) yang menyatakan bahwa terdapat hubungan antara sikap ilmiah dengan prestasi belajar peserta didik.

Nilai uji sebesar 0,215 pada hasil uji korelasi menunjukkan sikap ilmiah dan prestasi belajar memiliki korelasi dalam tingkat korelasi rendah. Rendahnya tingkat korelasi antara sikap ilmiah dan prestasi belajar pada penelitian ini dapat dikarenakan perubahan nilai sikap ilmiah dengan prestasi belajar yang tidak seimbang. Kondisi ini sesuai dengan Nurgiyantoro, Gunawan, \& Marzuki (2002: 124) yang menyatakan bahwa tinggi rendahnya tingkat korelasi variabel ukur dapat berdasarkan konsistensi dan sistematis nilai suatu variabel diikuti dengan nilai variabel lain.

Hasil uji korelasi yang menunjukkan korelasi antara sikap ilmiah dan prestasi belajar, dilakukan uji manova sebagai uji hipotesis. Uji manova digunakan untuk menguji peningkatan sikap ilmiah dan prestasi belajar peserta didik kelas XI SMA 1 Godean antara kelas eksperimen dan kelas kontrol. Digunakannya uji manova sebagai uji hipotesis penelitian karena nilai pengetahuan awal yang diperoleh dari nilai ulangan sebelumnya gagal menjadi kovariat atau lebih besar dari 0,05 yaitu 0,480 terhadap sikap ilmiah dan 0,923 terhadap prestasi belajar. Berdasarkan uji manova yang dilakukan diperoleh nilai signifikan sebesar 0,000. Hasil siginifikan yang lebih kecil dari 0,05 pada uji manova menunjukkan adanya peningkatan sikap ilmiah dan prestasi belajar peserta didik kelas XI SMA 1 Godean yang diberi penerapan LVK berbasis HTML5 dengan peserta didik yang tidak diberi penerapan LVK berbasis HTML5 pada materi Laju Reaksi.

Adanya peningkatan sikap ilmiah dan prestasi belajar peserta didik sesuai dengan hasil penelitain yang dilaporkan oleh Shah \& Khan (2015) yang menyatakan bahwa penerapan media dalam pembelajaran lebih efektif daripada pembelajaran konvensional. Pembelajaran dengan menggunakan media akan membuat proses pembelajaran menjadi lebih efektif, materi yang disampaikan lebih mudah dipahami peserta didik. Kondisi ini sesuai dengan Higgins, Xiao, \& Katsipataki (2012: 16) menyatakan bahwa dukungan teknologi dan interaksi dalam pendidik dengan peserta didik membuat pembelajaran menjadi lebih efektif dan memberikan dampak yang baik terhadap prestasi belajar peserta didik.

Peningkatan sikap ilmiah dan prestasi belajar peserta didik kelas XI SMA 1 Godean dengan penerapan LVK berbasis HTML5 berbeda dengan peningkatan peserta didik tanpa penerapan LVK berbasis HTML5 pada materi Laju Reaksi dipengaruhi oleh nilai sikap ilmiah peserta didik. Kondisi tersebut dibuktikan dengan nilai signifikansi yang diperoleh 0,00 atau kurang dari 0,05. 
(Fui, Lan, \& Kususanto, 2012) menyatakan bahwa sikap ilmiah merupakan kecenderungam, perasaan, dan tanggapan seseorang terhadap suatu objek untuk memberikan tanggapan secara ilmu pengetahuan. Berdasarkan observasi sikap ilmiah pada kelas eksperimen rerata nilai sikap ilmiah mengalami kenaikan dari pertemuan pertama hingga pertemuan keempat, sedangkan pada kelas kontrol cenderung tetap. Rerata sikap ilmiah kelas eksperimen dan kontrol dapat dilihat pada Gambar 1.

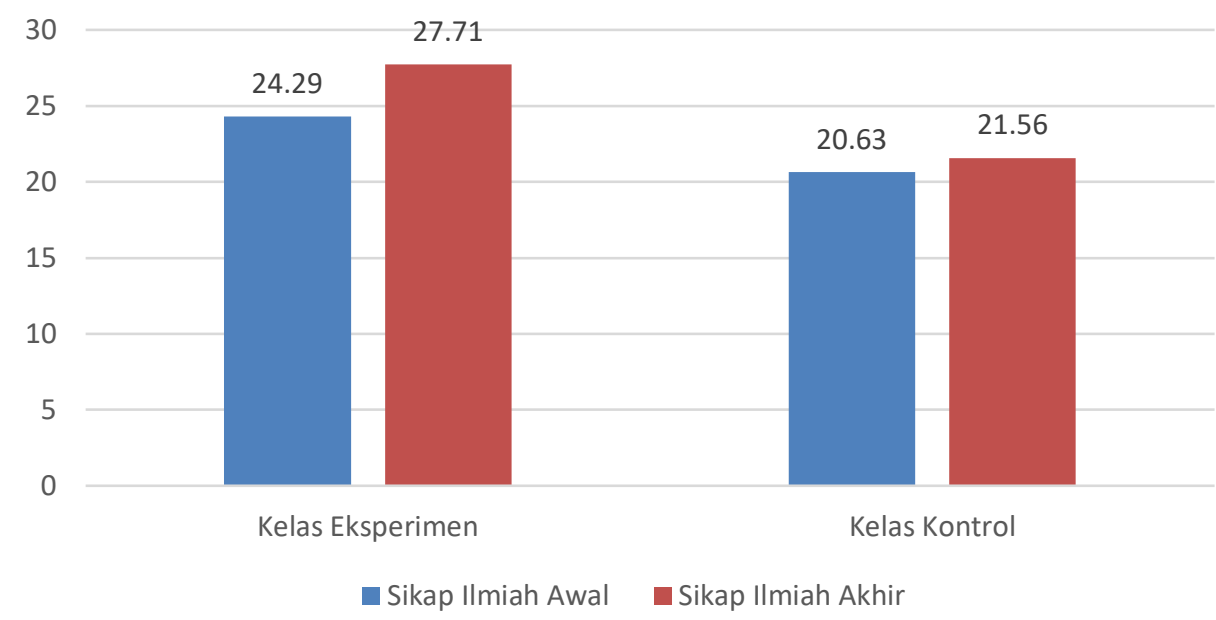

Gambar 1. Grafik Sikap Ilmiah

Rerata nilai sikap ilmiah peserta didik kelas eksperimen lebih tinggi daripada kelas kontrol baik sebelum maupun selama pembelajaran. Selisih rerata sikap ilmiah akhir dengan awal pada kelas eksperimen adalah 3,42 sedangkan pada kelas kontrol 0,93. Pada kelas eksperimen peningkatan sikap ilmiah peserta didik lebih tinggi dibanding kelas kontrol. Rendahnya sikap ilmiah peserta didik kemungkinan dipengaruhi oleh media pembelajaran yang diterapkan kurang menarik perhatian peserta didik dan terkesan monoton, sehingga peserta didik menjadi jenuh dan pasif dalam mengikuti proses pembelajaran. Kondisi ini sesuai dengan penelitian yang dilakukan oleh Ikhsan \& Afdal (2016) yang menyatakan pembelajaran di laboratorium memiliki karakteristik lingkungan belajar yang lebih tertutup dibanding menggunakan media laboratorium virtual, terpisah antara kenyataan dan imajinasi peserta didik, dan peserta didik kurang berpartisipasi aktif dalam pembelajaran.

Kenaikan nilai rerata sikap ilmiah sebesar 3,42 menunjukkan bahwa penerapan media pembelajaran LVK berbasis HTML5 dapat meningkatkan sikap ilmiah peserta didik, sedangkan media powerpoint yang diterapkan pada kelas kontrol tidak dapat meningkatkan sikap ilmiah peserta didik. Bedasarkan hasil observasi selama pembelajaran, peserta didik pada kelas eksperiemen cenderung lebih aktif dan rasa ingin tahu peserta didik terhadap materi yang disampaikan lebih tinggi bila dibandingkan dengan kelas kontrol. Kondisi pembelajaran yang tidak dapat mengaktifkan peserta didik dalam pembelajaran mengakibatkan proses pembelajaran menjadi kurang bermakna dan mengakibatkan rendahnya motivasi belajar peserta didik dalam pembelajaran. Konsisi ini sesuai dengan Bektasli (2013) dan Muhaimin, Susilawati, \& Soeprianto (2015) yang menyatakan bahwa penerapan media dapat meningkatkan sikap ilmiah peserta didik. Shah \& Khan (2015) yang menyatakan bahwa penerapan media dalam pembelajaran lebih efektif daripada pembelajaran konvensional. Pembelajaran dengan menggunakan media mengakibatkan peserta didik menjadi tertantang dan mengakibatkan peserta didik lebih aktif dalam mengikuti proses pembelajaran.

Adanya perbedaan tingkat sikap ilmiah peserta didik dimungkinkan karena beberapa faktor berikut:

1. Media LVK merupakan hal yang baru bagi peserta didik, sehingga peserta didik menjadi tertantang dan pembelajaran menjadi tidak membosankan, sehingga materi yang disampaikan dapat diterima dengan mudah oleh peserta didik. Kondisi ini sesuai dengan hasil penelitian yang dilakukan Tatli \& Ayas (2012) yang menyatakan bahwa pemanfaatan laboratorium virtual akan memberikan memberikan pengalaman peserta didik untuk melakukan percobaan secara interaktif dan meningkatkan memotivasi belajar.

2. Media LVK merupakan multimedia sehingga mengandung berbagai macam jenis media mengakibatkan peserta didik kelas eksperimen menjadi lebih termotivasi dalam mengikuti pembelajaran. Kondisi ini 
sesuai dengan hasil penelitian yang dilakukan Quddus, Hamid, \& Kasli (2017) yang menyatakan bahwa pemanfaatan media laroratorium virtual dapat menjadikan pembelajaran menjadi lebih menarik.

3. Penerapan media LVK berbasis HTML5 dapat menciptakan suasana belajar yang aktif. Kondisi ini sesuai dengan hasil penelitian yang dilakukan Ikhsan \& Afdal (2016) yang menyatakan penggunaan laboratorium virtual dalam pembelajaran dapat menjadikan peserta didik aktif.

4. LVK berbasis HTML5 memiliki fleksibilitas yang tinggi karena dapat digunakan kapan saja dan dimana saja. Kondisi ini sesuai dengan hasil penelitian yang dilakukan Chuang \& Chen (2007) yang menyatakan bahwa pemanfaatan media pembelajaran digital dapat memfasilitasi kegiatan belajar peserta didik dimanapun dan kapanpun.

Peningkatan sikap ilmiah dan prestasi belajar peserta didik kelas XI SMA 1 Godean yang diberi penerapan LVK berbasis HTML5 dengan peserta didik yang tidak diberi penerapan LVK berbasis HTML5 pada materi Laju Reaksi tidak dipengaruhi oleh nilai prestasi belajar peserta didik. Kondisi tersebut dibuktikan dengan nilai signifikansi yang diperoleh 0,297 atau lebih dari 0,05.

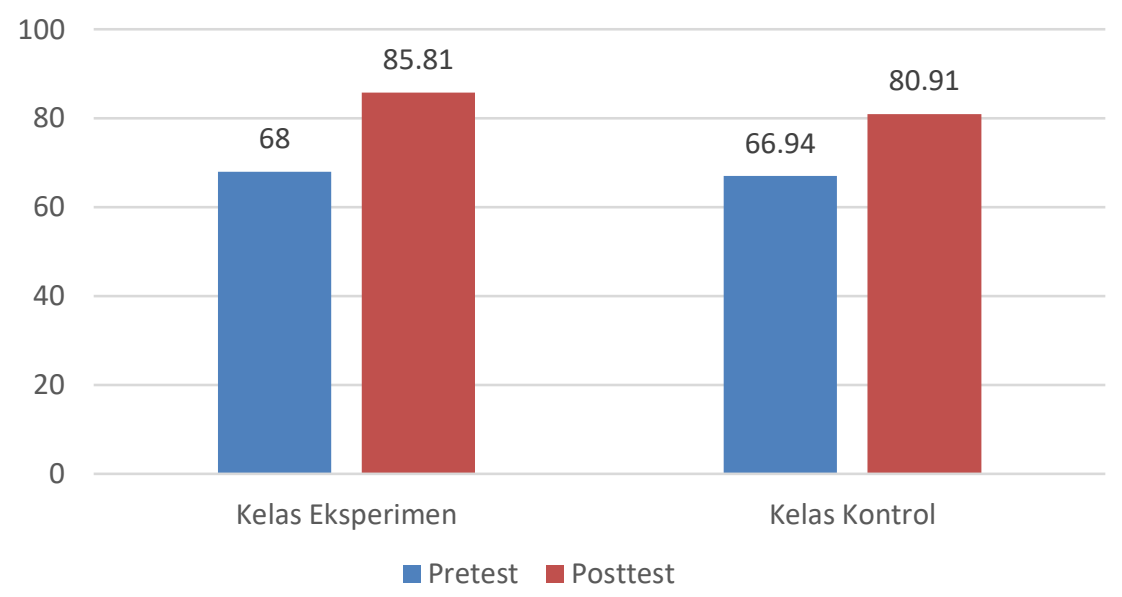

Gambar 2. Grafik Prestasi Belajar

Nilai awal peserta didik diperoleh dari nilai pretest, sedangkan nilai akhir diperoleh dari nilai posttest. Berdasarkan Gambar 2, nilai rerata baik kelas eksperimen dan kelas kontrol menunjukkan adanya peningkatan prestasi belajar peserta didik. Berdasarkan rerata nilai posttest terdapat selisih 4,9 antara kelas eksperimen dengan kelas kontrol yang menandakan rerta nilai kelas eksperimen lebih tinggi dibanding dengan kelas eksperimen. Peningkatan prestasi belajar peserta didik dimungkinkan karena beberapa faktor berikut:

Pembelajaran menggunakan LVK berbasis HTML5 lebih menarik perhatian peserta didik sehingga materi yang disampaikan dapat diterima dengan mudah dan bertahan lebih lama dalam ingatan peserta didik. Kondisi ini sesuai dengan hasil penelitian yang dilakukan Karpicke \& Roediger (2007) yang menyatakan laboratorium virtual sangat efektif untuk diterapkan karena materi, tugas peserta didik, dan kegiatan praktikum sudah terdapat dalam media pembelajaran, sehingga peserta didik lebih mudah dalam memahami materi yang disampaikan dan prestasi belajar dapat meningkat.

Materi yang bersifat abstrak dapat divisualisasikan dengan baik menggunakan LVK berbasis HTML5. Kondisi ini sesuai dengan hasil penelitian yang dilakukan Swandi, Hidayah, \& Irsan (2014) yang menyatakan laboratorium virtual merupakan serangkaian program komputer yang dapat memvisualisasikan fenomena yang abstrak atau percobaan yang rumit dilakukan di laboratorium nyata.

Adanya kenaikan prestasi belajar yang lebih besar pada kelas eksperimen dikarenakan penerapan LVK berbasis HTML5 yang memudahkan peserta didik dalam belajar. Kondisi ini sesuai dengan Francis \& Flanigan (2012) dan Bektasli (2013) yang menyatakan bahwa penerapan media dapat meningkatkan prestasi belajar peserta didik. Nurseto (2011) menyatakan bahwa fungsi media merupakan sarana untuk mewujudkan situasi pembelajaran yang lebih efektif dan meningkatkan kualitas pembelajaran. Penggunaan 
media dalam pembelajaran dapat mengefektifkan pembelajaran selama di kelas, karena peserta didik dapat memperlajari ulang di rumah dan mempelajari materi yang akan disampaikan pada pertemuan berikutnya.

Putri, Syakbaniah, \& Yulkifli (2013) menyatakan bahwa fungsi adanya laboratorium virtual dimaksudkan untuk menanamkan konsep yang meliputi persiapan dalam kegiatan praktikum yang akan dilakukan, tampilan laboratorium virtual untuk memvisualisasikan materi yang bersifat abstrak, dan evaluasi proses pembelajaran yang dilakukan. Pembelajaran dengan menggunakan laboratorium virtual memudahkan peserta didik dalam memahami materi, dan kegiatan praktikum dapat diulang sesuai kebutuhan peserta didik tanpa menghabiskan banyak bahan yang akan digunakan dalam kegiatan praktikum. Tatli \& Ayas (2010) menyatakan bahwa laboratorium virtual merupakan media alternatif untuk melakukan kegiatan praktikum secara mandiri.

Penerapan LVK berbasis HTML5 tidak adak menunjukkan adanya peningkatan prestasi belajar peserta didik dibanding peserta didik tanpa penerapan LVK berbasis HTML5. Tidak adanya perbedaan prestasi belajar peserta didik secara signifikan dimungkinkan karena beberapa faktor seperti tidak semua tempat memiliki koneksi internet, sehingga peserta didik tidak dapat membuka LVK berbasis HTML5, tampilan dan kelancaran dalam pengoperasian LVK berbasis HTML5 dipengaruhi perangkat yang digunakan peserta didik. Kondisi ini sesuai dengan hasil penelitian yang dilakukan Lubis \& Ikhsan (2015) yang menyatakan tampilan dalam media pembelajaran dipengaruhi oleh kualitas dan tipe perangkat yang digunakan, sehingga terkadang tidak dapat menampilkan materi kimia secara maksimal.

Scheckler (2003) menyatakan bahwa penggunaan laboratorium virtual dapat meningkatkan pemahaman peserta didik terhadap materi yang disampaikan. Oleh karena itu, penggunaan laboratorium virtual dengan praktikum langsung di laboratorium sekolah memiliki keefektifan yang sama dalam meningkatkan prestasi belajar peserta didik. Secara keseluruhan penelitian ini telah berhasil menunjukkan efektivitas LVK berbasis HTML5 dalam mengingkatkan sikap ilmiah dan prestasi belajar peserta didik, khusunya peserta didik kelas XI SMA Negeri 1 Godean. Lebih lanjut penelitan serupa dapat dilakukan oleh peneliti lain dengan materi Kimia yang lain.

\section{Kesimpulan}

Hasil penelitian menunjukkan terdapat peningkatan sikap ilmiah dan prestasi belajar yang lebih baik pada peserta didik kelas XI SMA 1 Godean dengan penerapan LVK berbasis HTML5 dibanding peserta didik tanpa penerapan LVK berbasis HTML5 pada materi Laju Reaksi.

\section{Referensi}

Aprianto. (2008). Pengaplikasian virtual laboratory sebagai media pembelajaran jarak jauh. Bandung: Program Pascasarjana Universitas Pendidikan Indonesia.

Ayodele, M. O. (2016). Attitude, self-concept and achievement of junior secondary school students in basic science in Ekiti State, Nigeria. Journal of Educational and Social Research, 6(1), 167.

Bayram, H., \& Comek, A. (2009). Social and behavioral sciences. Procedia, 1(1), 1526.

Bektasli, B. (2013). The effect of media on preservice science teachers' attitudes toward astronomy and achievement in astronomy class. The Turkish Online Journal of Educational Technology, 12(1), 139.

Chuang, T., \& Chen, W. (2007). Effect of digital games on children's cognitive achievement. Journal of Multimedia, 2(5), 27-30.

Francis, \& Flanigan. (2012). Self-Directed Learning and Higher Edu-cation Practices: Implications for Student Performance and Engagement. The International Journal of The Scholarship of Teaching and Learning, 7(3), 1-18.

Fui, C. S., Lan, L. H., \& Kususanto, P. (2012). Teachers' Expectancy and Students' Attitude towards Science. Journal of Education and Learning, 89. 
Higgins, S., Xiao, Z., \& Katsipataki, M. (2012). The Impact of Digital Technology on Learning: A Summary for the Education Endowment Foundation. Durham: Durham University.

Ikhsan, M., \& Afdal. (2016). Kajian motivasi belajar siswa dalam pembelajaran kimia menggunakan virtual lab. Jurnal Pendas Mahakam, 1(1), 66.

Karpicke, J., \& Roediger, H. (2007). Repeated Retrieval During Learning is The Key to Long-Term Retention. Journal of Memory and Language, 151-162.

Lubis, I. R., \& Ikhsan, J. (2015). Pengembangan media pembelajaran kimia berbasis android untuk meningkatkan motivasi belajar dan prestasi kognitif peserta didik SMA. Jurnal Inovasi Pendidikan $I P A, 200$.

Mendikbud. (2013). Elemen Perubahan Kurikulum 2013. Jakarta: Kementerian Pendidikan dan Kebudayaan.

Muhaimin, A., Susilawati, \& Soeprianto, H. (2015). Pengembangan media kapasitor dan pengaruhnya terhadap pemahaman konsep dan sikap ilmiah siswa. Jurnal Pendidikan Fisika Indonesia, 11(1), 59.

Narmadha, U., \& Chamundeswari, S. (2013). Attitude towards learning of science and academic achievement in science among students at the secondary level. Journal of Sociological Research, 4(2), 114.

Nurgiyantoro, B., Gunawan, \& Marzuki. (2002). Statistik Terapan untuk Penelitian Ilmu-ilmu Sosial. Yogyakarta: Gadjah Mada University Press.

Nurseto, T. (2011). Membuat media pembelajaran yang menarik. Jurnal Ekonomi \& Pendidikan, 8(1), 21-22.

Putri, A., Syakbaniah, \& Yulkifli. (2013). Pengembangan virtual laboratory pada materi kinematika dengan analisis vektor dalam pembelajaran fisika kelas XI SMA. Pillar of Physics Education, 1, 23-24.

Quddus, A., Hamid, T., \& Kasli, E. (2017). Perbandingan hasil belajar fisika dengan menggunakan laboratorium nyata dan laboratorium virtual. Jurnal Ilmiah Mahasiswa (JIM) Pendidikan Fisika, 2(1), 122-125.

Sadiman, A., Rahardjo, R., Haryono, A., \& Rahardjito. (1984). Media Pendidikan. Jakarta: Raja Grafindo Persada.

Scheckler, R. K. (2003). Virtual labs: A Subtitute for traditional labs?. International Journal Developmental Biology, 47(2), 231.

Shah, I., \& Khan, M. (2015). Impact of multimedia-aided teaching on students' academic achievement and attitude at elementary level. US-China Education Review A, 5(5), 349.

Singh, V. K., Singh, A. K., \& Giri, A. (2016). A study of the relationship between scientific attitude and academic achievement of rural area's intermediate college girls (science stream only). International Journal of Applied Research, 2(4), 46.

Stevens, P. James. (2009). Applied Multivariate Statistics For The So Cial Sciences. New York: Routledge.

Susilana, R., \& Riyana, C. (2008). Media Pembelajaran. Bandung: FIP UPI.

Swandi, A., Hidayah, S. N., \& Irsan, L. (2014). Pengembangan media pembelajaran laboratorium virtual untuk mengatasi miskonsepsi pada materi fisika inti di SMAN 1 Binamu, Jeneponto. Jurnal Fisika Indonesia, 52(18), 21. 
Tatli, Z., \& Ayas, A. (2010). Virtual laboratory applications in chemistry education. Procedia Social and Behavioral Sciences, 938.

Tatli, Z., \& Ayas, A. (2012). Virtual chemistry laboratory: effect of constructivist learning environment. Turkish Online Journal of Distance Education, 13 (1), 185.

Vijayakumara, \& Lakshmi, N. (2016). Study of scientific attitude in relation to academic achievement of science students studying in IX standard of mysore. International Journal of Informative \& Futuristic Research, 4(3), 5515. 